\title{
Asthma and the common cold: can viruses imitate worms?
}

Exacerbations of asthma often occur during acute viral respiratory infections, ${ }^{12}$ but no consensus has been reached as to whether they can initiate asthma in the first instance. One view is that acute viral respiratory infections damage the bronchial epithelium, and that this damage can lead to asthma. ${ }^{3}$ The other is that a predisposition (genetic or otherwise) is required to allow this to happen, and only transient damage occurs in previously normal individuals. ${ }^{4}$

There is a strong link between infantile bronchiolitis and the asthmatic symptoms in later childhood. ${ }^{5-7}$ In one uncontrolled prospective study of 48 children with bronchiolitis $92 \%$ were diagnosed as asthmatic at some time within the ensuing five years. ${ }^{8}$ In another study 73 children admitted to hospital with infantile bronchiolitis were followed for an average of 5.5 years; $42.5 \%$ reported wheezing within the final year compared with $15 \cdot 1 \%$ of controls. ${ }^{9}$ The frequency of asthmatic symptoms appears to decline with time and may disappear between the ages of 8 and 13 years. ${ }^{10}$ Other studies suggest that hyperresponsiveness to inhaled histamine may persist for 10 years or more after acute bronchiolitis, ${ }^{11}$ and might even predispose to pulmonary disease in adult life. ${ }^{12-14}$ Some studies $^{56815}$ show no evidence that an atopic predisposition is required for bronchial hyperreactivity to develop, although others are equivocal ${ }^{9}$ or suggest that atopy strengthens the association..$^{16-19}$

These apparently conflicting views as to whether viral infections can initiate asthma are reconcilable, and fig 1 shows how both standpoints may be accommodated. According to this scheme, viruses cause epithelial damage in normal individuals which tends to resolve completely and rarely causes wheezing or chronic epithelial inflammation. In a genetically predisposed individual (or one already predisposed by previous or concurrent infection, bronchiectasis, or inhalation of irritants) the acute epithelial damage is more likely to be complicated by wheeze or by the vicious cycle of chronic inflammation, predisposing to further acute damage with subsequent virus infections. These chronic changes provide the setting for the lymphocytic $^{20}$ and eosinophilic ${ }^{21}$ bronchitis which is seen in chronic asthma, and for the consequent bronchial hypersensitivity and airflow obstruction.

One intriguing question is whether the association between virus-mediated epithelial damage and asthma is one of chance, or the consequence of sophisticated survival strategies evolved by viruses. The number and diversity of common cold viruses suggests that they occupy a particularly desirable ecological niche. Over millions of years of co-evolution an equilibrium may have been reached whereby the injury which they cause is the least that is compatible with the optimal dissemination to other individuals, while allowing the maintenance of the social activities which are essential to viral spread. This contrasts with new viruses (such as HIV) which appear relatively maladapted, immunologically crude, and often lethal. If these generalisations are correct, it might be expected that old and well adapted viruses would have had the opportunity and motive to acquire subtle and specific abilities to modify host immune responses to their own advantage.

Recent work indicates that this may well be so, at least for respiratory syncytial virus (RSV). This pathogen causes most cases of bronchiolitis in children and regularly reinfects adults, causing colds. We have focused on isolating and testing specific immune responses to viral antigens from RSV, in particular on studies of $T$ cells in the mouse (an animal which has contributed more to modern immunology than any other species). In 1988 we showed that $\mathrm{CD} 8+\mathrm{MHC}$ class I restricted cytotoxic $\mathrm{T}$ lymphocytes were able to kill virus-infected cells and eliminate infection in vivo. However, a high level of cytotoxic T lymphocyte activity early during infection also causes severe lung damage, with changes on bronchial lavage which resemble those of shock lung (adult respiratory distress syndrome). ${ }^{22}$ This augmentation of disease is reminiscent of the problems seen in the 1960 s when a killed RSV vaccine produced disease of increased severity in many of the children who subsequently became infected.

Recently the role of CD 4 + helper $T$ (Th) cells in RSV infection has gained prominence. Analysis of mouse $\mathrm{T}$ cell lines and clones indicates that $\mathrm{Th}$ cells are subdivided into at least two broad classes, illustrated in fig 2 . Th1 cells are those classically induced by large particulate antigens and by intracellular pathogens, particularly viruses. They are typically induced by moderately high doses of antigen, delivered by macrophages and dendritic cells. ${ }^{23}$ Th1 cells produce IL-2, which acts as an autocrine growth factor, and tumour necrosis factor (TNF) which induces an

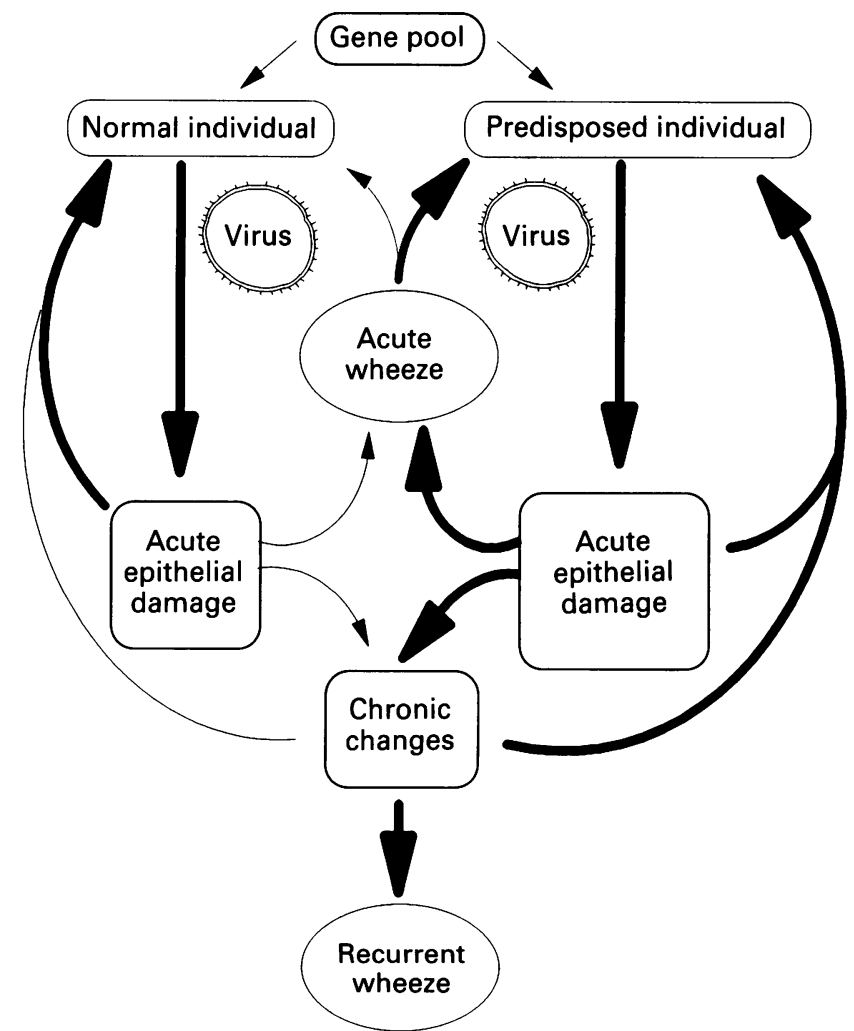

Figure 1 Relation between acute virus infection and asthma. According to this scheme, it is easier to establish a vicious cycle of inflammation in a predisposed individual. Predisposition may also occur by repeated or concurrent infections in genetically non-predisposed individuals. With treatment or a change in environment, chronic changes can revert to a state of predisposition, or even normality. The influence of other environmental factors such as allergen exposure, inhalation of smoke, or air pollution is not shown, but may have additive or multiplicative effects at any stage. 
antiviral state in cells bearing TNF receptors. They are involved in delayed hypersensitivity reactions and provide help for cytotoxic $\mathrm{T}$ cells. On the other hand, extracellular pathogens (including helminths) and high antigen concentrations tend to induce predominantly Th2 responses. In this case B cells may be important antigen presenting cells. ${ }^{23}$ Th2 cells produce IL-4, which acts as an autocrine growth factor and assists mast cell and IgE production, ${ }^{24}$ and IL-5, which is an eosinophil chemoattractant and growth factor. ${ }^{25}$ In any particular site these subsets (Th1 and Th2) vie with each other to establish dominance: Th2 cells produce IL-10 which inhibits growth and function of Th1 cells, while Th1 cells produce $\gamma$ interferon ( $\gamma$ IFN) which inhibits Th2 cell activity. ${ }^{26}$ This conflict produces an unstable balance, so that local inflammation will tend to be dominated by one or other of these cell types. Peaceful co-existence is not the favoured state.

Respiratory syncytial virus contains a most unusual attachment protein called glycoprotein G. This protein has an exceptional level of $O$-glycosylation, so that carbohydrate makes up some $63 \%$ of its mass. The function of this carbohydrate is unknown, but may have some role in attachment. The protein also has a secreted (soluble) form ${ }^{27}$ which lacks the normal transmembrane anchor and has been suggested to act as an extracellular decoy for the immune response. When we came to test vaccinia recombinant viruses which express this protein (kindly provided by Professor G Wertz, Birmingham, Alabama, USA) we found a striking immunological effect. Mice sensitised to this protein develop an eosinophilic pneumonitis on subsequent infection with RSV. Under these circumstances eosinophils often make up $20-60 \%$ of all lung cells recovered by bronchoalveolar lavage, ${ }^{28}$ a level unprecedented in other studies of viral lung disease. This effect appears to be due to virus-specific Th2 cells which recognise the glycoprotein $G$, and is not due to reaginic antibody. Such levels of pulmonary eosinophilia have only previously been seen in animals infected with helminths. Switching host immunity to an "antihelminthic" mode (fig 3 ) could be advantageous to the virus. Th2 cells would have a counterinhibitory effect on Th1 responses in the respiratory tract, which should theoretically be those more effective at limiting virus replication. In addition, mucus hypersecretion, coughing, and sneezing could assist in

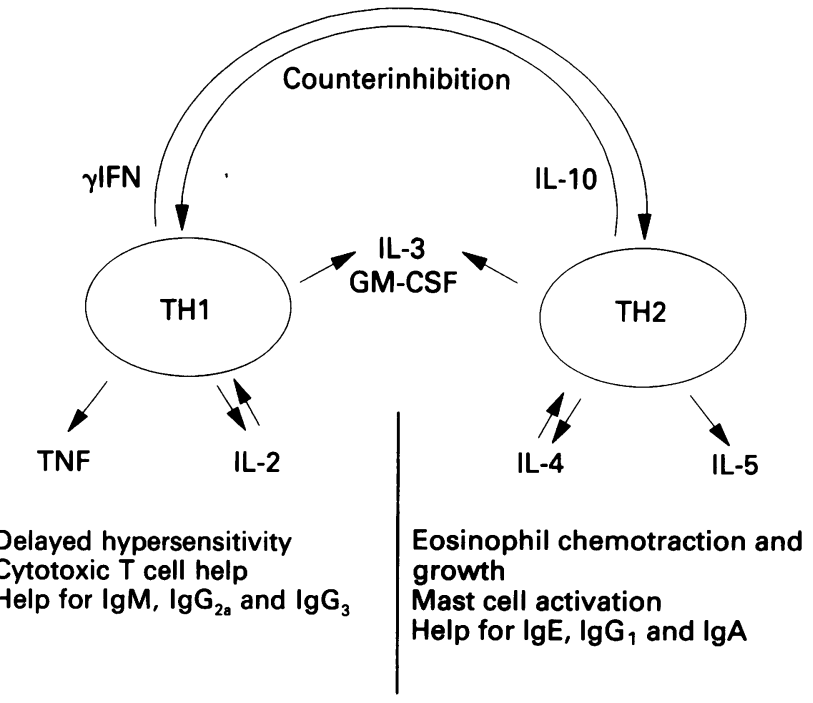

Figure 2 Counterinhibitory link between helper $T$ cell subsets. $T$ helper 1 (Th1) cells are typical antiviral immune effectors and are central to coordination of classic immune responses to antigens presented by macrophages and dendritic cells. Th2 cells appear to be specialised for antihelminthic responses but are prominent in the asthmatic airway. $\gamma I F N=$ gamma interferon; $G M-C S F=$ granulocyte macrophage colony stimulating factor. dissemination of the virus; wheezing could perhaps be a mere side effect.

We do not yet know how the $G$ protein causes this aberrant immune response, but studies of other viruses have shown that subtle, specific interference of viral proteins with the immune system can occur. For example, when the gene for IL-10 was first cloned a search of genetic databases revealed a close homology with a gene of unknown function (BCRF1) in Epstein-Barr virus. ${ }^{29}$ It turns out that the partial IL-10 homologue produced by this viral gene retains certain of the natural actions of IL10 , while lacking others. In particular, it can act as B cell growth factor (producing more of the very cells which Epstein-Barr virus infects), inhibiting TNF and $\gamma$ IFN (both of which might assist in the development of antiviral immunity). It has been suggested that the Epstein-Barr virus picked up this gene from the host during co-evolution of man and parasite. Although no in vivo effects of this apparent molecular mimicry have been demonstrated with certainty, it has recently been suggested that dual infections with the Epstein-Barr virus and malaria in early infancy may cause malarial antigens to be recognised abnormally, and for the immune response to be skewed towards a non-pathogenic Th2 pattern. ${ }^{30}$ Once this pattern is established the same type of response might again be favoured during subsequent reinfections with malaria, causing the clinical severity of such infections to be reduced.

There are several other examples of viral proteins which may act as "spanners" in the immunological works. The major protein secreted by cells infected with myxoma virus is a $37 \mathrm{kD}$ soluble polypeptide with sequence homology to the mammalian $\gamma$ IFN receptor (which is normally membrane bound). This viral protein binds free $\gamma$ IFN, preventing the induction of antiviral immunity. ${ }^{31}$ Secondly, several viruses of the pox virus family have been found to contain a gene which encodes a viral protein, T2. This causes host cells to secrete a soluble TNF binding protein which acts as an extracellular decoy for TNF and competes with TNF to prevent its binding to the TNF receptor, which would otherwise induce an antiviral state in neighbouring cells. ${ }^{32}$ Adenoviruses can also act on this

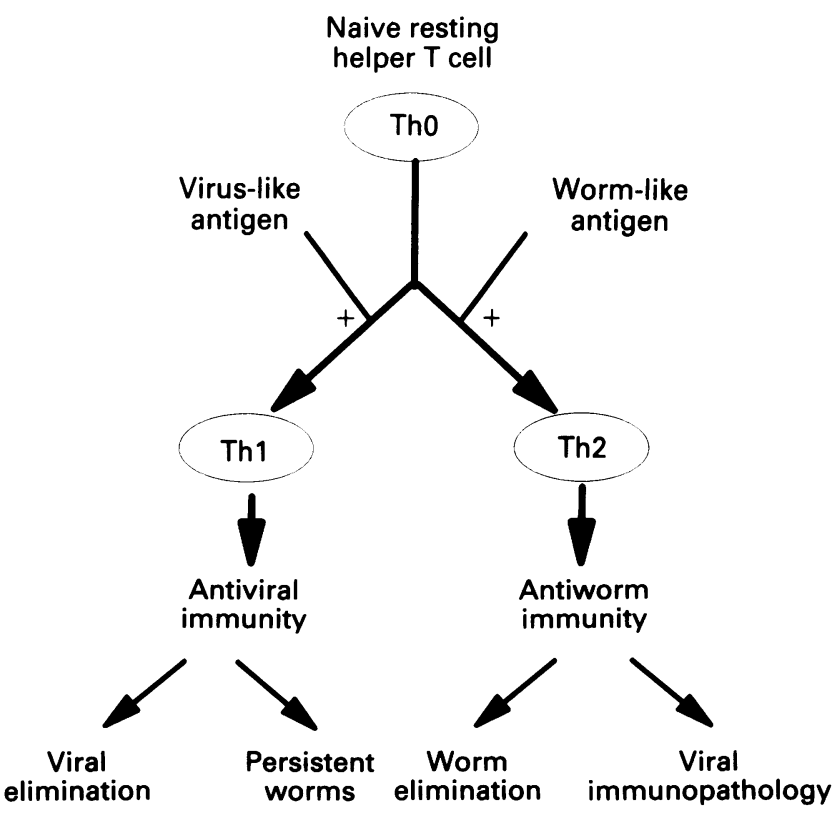

Figure 3 Pathways of helper $T$ cell immunity. Uncommitted helper $T$ cells (Th0) differentiate to Thelper 1 (Th1) or Th2 cells when exposed to antigen in a form which is interpreted by the immune system as indicating the nature of the pathogen. The ability to trick the immune system into developing the "wrong" type of response would be advantageous to a pathogen. 
pathway, producing three intracellular proteins which block the cellular effects of TNF ${ }^{33}$ In addition, adenovirus 2 appears to be able to inhibit the induction of class I MHC after virus infection, ${ }^{34}$ thereby preventing signalling to $\mathrm{CD} 8+\mathrm{T}$ cells. It seems probable that, as more is known about the ways in which the immune system acts and more viral proteins are sequenced and studied, more such interactions will emerge.

\section{Conclusions}

Asthma and acute viral respiratory infections are both among the commonest of respiratory afflictions. There is a strong association between viral respiratory infections and both the onset and exacerbation of asthma, and the nature of this association is an important area for future research. Recent information suggests that this link may not be wholly accidental but may reflect specific interactions of viral proteins with the host immune system. Delayed effects of viral infection can arise in curious and novel ways; we must look for viral effects free of preconceived notions about the normal site or duration of infection. This may only be possible using the latest molecular techniques, particularly the polymerase chain reaction. Finally, the host immune system is not fixed at birth; previous and concurrent infections could produce long term effects which predispose to disease in later life.

We thank The Wellcome Trust and The British Lung Foundation for support.

\section{Respiratory Unit,}

St Mary's Hospital Medical School,

P J M OPENSHAW

London W2 $1 P G$, UK

Reprint requests to: Dr P J M Openshaw.

1 McIntosh K, Ellis EF, Hoffman LS, Lybass TG, Eller JJ. The association of viral and bacterial respiratory infections with exacerbations of wheezing in young asthmatic children. $\mathcal{F}$ Pediatr 1973;83:578-90.

2 Beasley R, Coleman ED, Hermon Y, Holst PE, O'Donnell TV, Tobias M Viral respiratory tract infection and exacerbations of asthma in adult patients. Thorax 1988;43:679-83.

3 Pattemore PK, Johnston SL, Bardin PG. Viruses as precipitants of asthma symptoms. I. Epidemiology. Clin Exp Allergy 1992;22:325-36.

4 Burney PGI. Epidemiology [of asthma]. Br Med Bull 1992;48:10-22.

5 Webb MSC, Henry RL, Milner AD, Stokes GM, Swarbrick AS. Continuing problems three and a half years after acute viral bronchiolitis. Arch Dis Child 1985;60:1064-7

6 Sims DG, Downham MAPS, Gardner PS, Webb JKG, Weightman D. Study of 8-year-old children with a history of respiratory syncytial virus bronchiolitis in infancy. $B M F$ 1978;1:11-4.

7 Eisen AH, Bacal HL. The acute relationship of acute bronchiolitis to bronchial asthma: a 4 to 14 year follow up. Pediatrics 1963;31:859-61.
8 Sly PD, Hibbert ME. Childhood asthma following hospitalization with acute viral bronchiolitis in infancy. Pediatr Pulmonol 1989;7:153-8.

9 Murray M, Webb MSC, O'Callaghan C, Swarbrick AS, Milner AD Respiratory status and allergy after bronchiolitis. Arch Dis Child 1992;67:482-7.

10 Connochie KM, Roghmann KJ. Wheezing at 8 and 13 years: changing importance of bronchiolitis and passive smoking. Pediatr Pulmonol 1989;6:138-46.

11 Pullan CR, Hey EN. Wheezing, asthma and pulmonary dysfunction 10 years after infection with respiratory syncytial virus in infancy. $B M F$ 1982;284:1665-9.

12 Barker DJP, Osmond C. Childhood respiratory infection and adult chronic bronchitis in England and Wales. BMf 1988;293:1271.

13 Samet JM, Tager IB, Speizer FE. The relationship between respiratory illness in childhood and chronic airflow obstruction in childhood. Am Rev Respir Dis 1983;127:508-23.

14 Barker DJ, Godfrey KM, Fall C, Osmond C, Winter PD, Shaheen SO. Relation of birth weight and childhood respiratory infection to adult lung function and death from chronic obstructive airways disease. $B M \mathscr{F}$ 1991;303:671-5.

15 Wilson NM, Phagoo SB, Silverman M. Atopy, bronchial responsiveness, and symptoms in wheezy 3 year olds. Arch Dis Child 1992;67:491-5.

16 Wennergren G, Hansson S, Engström I, Jodal U, Åmark M, Brolin I, et al. Characteristics and prognosis of hospital-treated obstructive bronchitis in children aged less than two years. Acta Paediatr Scand 1992;81:40-5.

17 Rooney JC, Williams HE. The relationship between proven and viral bronchiolitis and subsequent wheezing. $B M \mathcal{F}$ 1971;79:744-7.

18 Nagayama Y, Sakurai N, Nakahara T, Makuta M, Honda A, Funabashi S, et al. Allergic predisposition among infants with bronchiolitis. $\mathcal{F}$ Asthma 1987;24:9-17.

19 Weiss ST, Tager IB, Munoz A, Speizer FE. The relationship of respiratory infections in early childhood to the occurrence of increased levels of bronchial responsiveness and atopy. Am Rev Respir Dis 1985;131:573-8.

20 Robinson DS, Hamid Q, Ying S, Tsicopoulos A, Barkans J, Bentley AM, et al. Predominant $\mathrm{T}_{\mathrm{H} 2}$-like bronchoalveolar $\mathrm{T}$-lymphocyte population in atopic asthma. N Engl F Med 1992;326:298-304.

21 Holgate ST, Roche WR, Church MK. The role of the eosinophil in asthma. Am Rev Respir Dis 1991;143(Suppl):S66-S70.

22 Cannon MJ, Openshaw PJM, Askonas BA. Cytotoxic T cells clear virus but augment lung pathology in mice infected with respiratory syncytial virus. augment lung pathology in mice

23 Stohlman SA. Accessory cells control induction of CD4 $+\mathrm{T}$ cells with specific effector function. Res Immunol 1991;142:50-4.

24 Paul WE. Interleukin-4: a prototypic immunoregulatory lymphokine. Blood 1991;77:1859-70.

25 Sanderson CJ. Interleukin-5, eosinophils, and disease. Blood 1992;79:3101-

26 Coffman RL, Mosmann TR. CD4 + T-cell subsets: regulation of differentiation and function. Res Immunol 1991;142:7-9.

27 Hendricks D, McIntosh K, Patterson J. Further characterization of the soluble form of the $\mathrm{G}$ glycoprotein of respiratory syncytial virus. $\mathcal{F}$ Virol 1988;62:2228-33.

28 Openshaw PJ, Clarke SL, Record FM. Pulmonary eosinophilic response to respiratory syncytial virus infection in mice sensitized to the major surface glycoprotein G. Int Immunol 1992;4:493-500.

29 Hsu D-H, De Waal Malefyt R, Fiorentino DF, Dang M-N, Vieira P, DeVries J, et al. Expression of interleukin-10 activity by Epstein-Barr virus protein BCRF1. Science 1990;250:830-2.

30 Watier H, Auriault C, Capron A. Does Epstein-Barr virus infection confer selective advantage to malaria-infected children? Lancet 1993;341:612-3.

31 Upton C, Mossman K, McFadden G. Encoding of a homolog of the IFNgamma receptor by myxoma virus. Science 1992;258:1369-72.

32 Smith CA, Davis T, Wignall JM, Din WS, Farrah T, Upton C, et al. T2 open reading frame from the Shope fibroma virus encodes a soluble form of the TNF receptor. Biochem Biophys Res Commun 1991;176:335-42.

33 Gooding LR. Virus proteins that counteract host immune defenses. Cell 1992;71:5-7.

34 Jefferies WA, Burgert H-G. E3/19K from adenovirus 2 is an immunosubversive protein that binds to a structural motif regulating the intracellular transport of major histocompatibility complex class I proteins. $\mathcal{f}$ Exp Med 1990;172:1653-64. 